\title{
Ocorrência de Curtobacterium flaccumfaciens pv. flaccumfaciens em Feijoeiro, em Goiás e no Distrito Federal
}

\author{
Carlos H. Uesugi ${ }^{1}$, Marcos A. Freitas ${ }^{1}$ \& José R. Menezes ${ }^{2}$ \\ ${ }^{1}$ Departamento de Fitopatologia, Universidade de Brasília, Cx. Postal 4457, CEP 70.910-900, \\ Brasília-DF, Fax (061) 272-1793, e-mail: uesugich@unb.br, ${ }^{2}$ Consultor Técnico
}

(Aceito para publicação em 07/01/2003)

Autor para correspondência: Carlos H. Uesugi

\begin{abstract}
First occurrence of Curtobacterium flaccumfaciens pv. flaccumfaciens on bean in the State of Goias and Federal District of Brazil

The bacterial wilt of bean (Phaseolus vulgaris) was observed in November 2000 in Goias and in January 2001 in the Federal District

of Brazil. Biochemical, physiological and pathogenicity tests confirmed the causal agent as Curtobacterium flaccumfaciens pv. flaccumfaciens. This is the first report of the disease in the State of Goias and in the Federal District of Brazil.
\end{abstract}

como postulado por Maringoni \& Rosa (Summa Phytopathol. 23:160, 1997). A repercussão da incidência e disseminação deste patógeno na cultura do feijoeiro deveria ser avaliada. Estirpes estão preservadas na Coleção de Bactérias Fitopatogênicas do Laboratório de Fitopatologia da Universidade de Brasília, Brasília, DF.

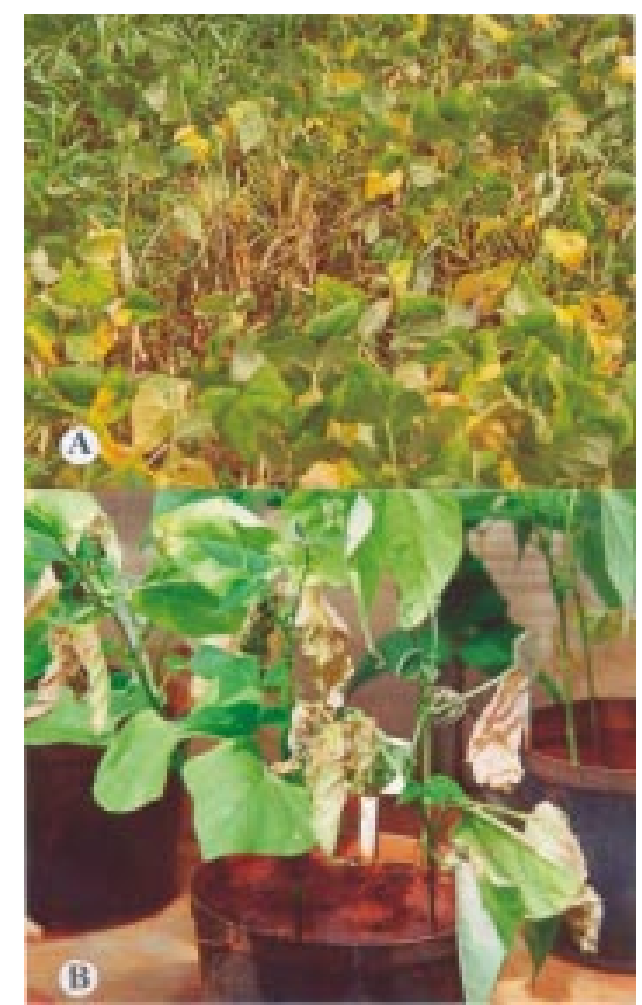

FIG. 1 - Murcha do feijoeiro (Phaseolus vulgaris), causada por Curtobacterium flaccumfaciens pv. flaccumfaciens, (A) em campo e (B) na cv. Pérola, inoculada com suspensão de células da bactéria através de ferimentos na haste com agulha de injeção 